\title{
Physiological aspects and yield in coffee progenies with large beans
}

\author{
João Paulo Silva Pavan ${ }^{1}$ (D), Cyntia Stephânia dos Santos ${ }^{2}$ (D), Ana Flávia de Freitas ${ }^{3}$ (D), \\ Samuel Pereira de Carvalho ${ }^{2}$ (D), Gladyston Rodrigues Carvalho ${ }^{3}$ (D)
}

${ }^{1}$ Instituto Agronômico de Campinas/IAC, Campinas, SP, Brasil

${ }^{2}$ Universidade Federal de Lavras/UFLA, Lavras, MG, Brasil

${ }^{3}$ Empresa de Pesquisa Agropecuária de Minas Gerais/EPAMIG, Lavras, MG, Brasil

Contact authors: joaosilvapavan@gmail.com; cyntia.s.santos@hotmail.com; ninhadtna13@hotmail.com; samuelpc@ufla.br; grodriguescarvalho@gmail.com

Received in August 18, 2020 and approved in April 20, 2021

\section{ABSTRACT}

Genetic coffee breeding is aimed at increasing yield associated with tolerance or resistance to biotic and abiotic factors, besides providing a better beverage quality and supplying the demand for bigger beans. The efficiency in photosynthetic activity can limit produce and diversify genotypes, mainly under adverse environmental conditions. Consequently, the importance of selection of Coffea arabica L. regarding these characteristics stands out. Therefore, the objective of this paper was to measure the physiological characterization and yield of Coffea arabica L. progenies with large beans "Big Coffee VL". Twelve productive progenies were selected and classified according to fruit size ("small", "medium" and "large"), which were: S14, S23, S34, S36, M4, M5, M14, M20, L10, L12, L17 and L31. Net photosynthetic rate (A), stomatal conductance (gs), transpiration rate (E), water use efficiency (WUE), internal carbon ( $\mathrm{Ci}$ ), intercellular $\mathrm{CO}_{2}$ concentration in the mesophyll were evaluated on the current external $\mathrm{CO}_{2}$ concentration (Ci/Ca), besides vapor pressure deficit (VPD), leaf temperature (Tleaf), indirect determination of the relative levels of chlorophylls $a, b$ and total, in addition to bean yield in two crops. The Tocher grouping resulted in the formation of 4 groups, and progenies M4, L10 and S34 remained in isolated groups.Progeny L10 stood out for higher mean values of $\mathrm{A}$, gs and $\mathrm{Ci}$; the opposite behavior was observed in progeny S34. Progeny M4 is noteworthy as the one with the highest yield in the two years considered, in addition to presenting high photosynthetic rate and chlorophyll indexes. It is concluded that the progenies of "Big Coffee VL" show variability for physiological parameters and productivity. Progenies S14, M4 and L10 stood out, and S14 was more efficient in the use of water; M4 was the most productive and L10 stood out in terms of gas exchange.

Key words: Chlorophyll; Coffea arabica L.; Gas exchange; Genetic breeding.

\section{INTRODUCTION}

The coffee crop has a relevant representativeness in Brazil, in terms of statistics on production volumes, exports, domestic consumption, in addition to the creation of jobs and income (Sakiyama et al., 2015). In 2020, the cultivated area of Arabica and Conilon coffee was 2.16 million hectares, an increase of $1.4 \%$ in relation to 2019 . The final result of the harvest reached 48.77 million bags. Arabica and Conilon coffee yield was 14.31 million bags (Companhia Nacional de Abastecimento - CONAB, 2020). In the Brazilian agribusiness, coffee is one of the most prominent commodities in foreign sales (Conselho dos Exportadores de Café do Brasil - CECAFÉ, 2018).

Much is due to genetic coffee breeding, which began with empirical breeding through the introduction of exotic cultivars, such as Typica, Sumatra and Bourbon. Posteriorly, cultivars with agronomic interest characteristics were achieved: yield, tolerance or resistance to pathogens and cup quality (Carvalho et al., 2008). Currently, yield is still the pivot of breeding programs, together with other characteristics, such as: multiple resistance to pathogens, pests and tolerance to abiotic stress, besides providing the niche markets with differentiated beverage quality and large beans (Ferreira et al., 2013; Silva et al., 2016; Venturin et al., 2013).

In this context, thirty years ago, in the county of Capitólio, at the Midwest of Minas Gerais, cultivar Acaiá, a coffee tree that produced larger leaves and fruits compared to conventional ones, was found at the field, allegedly originated due to genetic mutation. It was spread and cultivated in Piumhi-MG, and was called "Big Coffee VL". Segregation was observed between plants, chiefly for the height and size of leaves and fruits. Therefore, a classification like "Small", "Medium" and "Large" was proposed (Silva et al., 2016).

In 2012, beginning with the seed collection from Piumhi progenies, a large-bean coffee breeding program began at the Federal University of Lavras (UFLA), which is in the evaluation phase. In recent studies, even greater genetic variability among progenies was observed, some of which are promising for breeding programs that intend beyond enhancing bean size (Silva et al., 2016) and tolerance to abiotic stress.

The selection of plants tolerant to stress has been the focus of research, primarily with the goal to mitigate the damage caused by climate change (DaMatta et al., 2019; Durand et al., 2019; Garcia et al., 2020). The plant activates defense mechanisms when subjected to a stress condition, such as enzymatic responses, gene activation, plus anatomical and physiological adaptations. These responses may diversify between genotypes of the same species (Castanheira et al., 2016; Durand et al., 2019; Rodrigues et al., 2016). Once it is a perennial crop, coffee tree selection in breeding programs is carried out over several years. In this context, it is relevant to use alternatives that might anticipate this process (Cilas; Montagnon; Bar-hen, 2011). 
Therefore, studies on physiology combined with coffee productivity can identify the variability among "Big Coffee VL" progenies, contributing to the selection of promising genotypes in breeding programs. In this perspective, the objective of this study was to assess the physiological characteristics and productivity of "Big Coffee VL" progenies.

\section{MATERIAL AND METHODS}

\subsection{Experimental area characterization}

The experiment was set in the Agriculture Department of the Federal University of Lavras (UFLA), state of Minas Gerais, Brazil, at $910 \mathrm{~m}$ altitude and $21^{\circ} 14^{\prime} 06^{\prime \prime} \mathrm{S}, 45^{\circ} 00^{\prime} 00^{\prime} \mathrm{W}$.

In 2012, 100 "Big Coffee VL" progenies from Piumhi, Minas Gerais, were deployed at a $3.5 \times 0.9 \mathrm{~m}$ spacing and distributed in a square lattice scheme. Of these, a classification based on bean size was settled, separated into three groups. They were: "Small" group, consisting of 32 progenies; "Medium" group, with 36 progenies and 32 progenies belonging to the "Large" group. For the current study, 12 progenies more vigorous and with higher yield were selected in relation to evaluations and results obtained by Silva et al. (2016).

The climatic condition in the year of assessment of this study was characterized by annual averages of temperature, relative humidity and rainfall of approximately $22^{\circ} \mathrm{C}, 69 \%$ and $3.5 \mathrm{~mm}$, respectively (Figure 1 and 2) (Instituto Nacional de Meteorologia - INMET, 2021).

\subsection{Experimental design}

A completely randomized design with 12 progenies and 3 replicates was considered, matching to the progenies of group S (progenies: 14, 23, 34 and 36), $\mathrm{M}$ (progenies: 4, 5, 14 and 20) and L (progenies: 10, 12, 17 and 31).

\subsection{Evaluated parameters}

\subsubsection{Gas exchange}

In June 2018, for the physiological evaluations, fully expanded leaves were selected from the third or fourth node of plagiotropic branches, in the middle third of each progeny.

A portable infrared gas analysis system (IRGA LICOR - 6400XT) was used for gas exchange evaluation. The following physiological variables were measured: Net photosynthetic rate $\left(\mathrm{A}-\mu \mathrm{mol} \mathrm{CO}_{2} \mathrm{~m}^{-2} \mathrm{~s}^{-1}\right)$, stomatal conductance (gs- mol $\mathrm{H}_{2} \mathrm{O} \mathrm{m}^{-1} \mathrm{~s}^{-1}$ ), transpiration rate $(\mathrm{E}$ - mmol $\mathrm{H}_{2} \mathrm{O} \mathrm{m}^{-2} \mathrm{~s}^{-1}$ ), water use efficiency (WUE - A/E $\mu \mathrm{mol} \mathrm{CO}_{2} / \mathrm{mol} \mathrm{H}_{2} \mathrm{O}$ ), internal carbon $\left(\mathrm{Ci}-\mu \mathrm{mol} \mathrm{CO}_{2}\right.$ $\mathrm{mol}^{-1}$ ), intercellular $\mathrm{CO}_{2}$ concentration in the mesophyll over current external $\mathrm{CO}_{2}$ concentration $(\mathrm{Ci} / \mathrm{Ca}$ ratio $\mu \mathrm{mol} \mathrm{CO}_{2}$ ), vapor pressure deficit (VPD - hPa), and leaf temperature (Tleaf $-{ }^{\circ} \mathrm{C}$ ), performed between 8 and 11 a.m., under saturating light $\left(1000 \mu \mathrm{mol} \mathrm{m} \mathrm{m}^{-2} \mathrm{~s}^{-1}\right)$.

\subsubsection{Chlorophyll index}

The indirect determination of the relative levels of chlorophylls a, b and total were obtained by a portable chlorophyll meter ClorofiLOG (Falker Automação Agrícola, Brasil), in June 2018, which provides values called Falker Chlorophyll Indexes (FCI), proportional to the chlorophyll absorbance. The ChlorofiLOG is an effective device in the indirect determination of the relative levels of chlorophylls a, b and total (Barbieri Júnior et al., 2012).

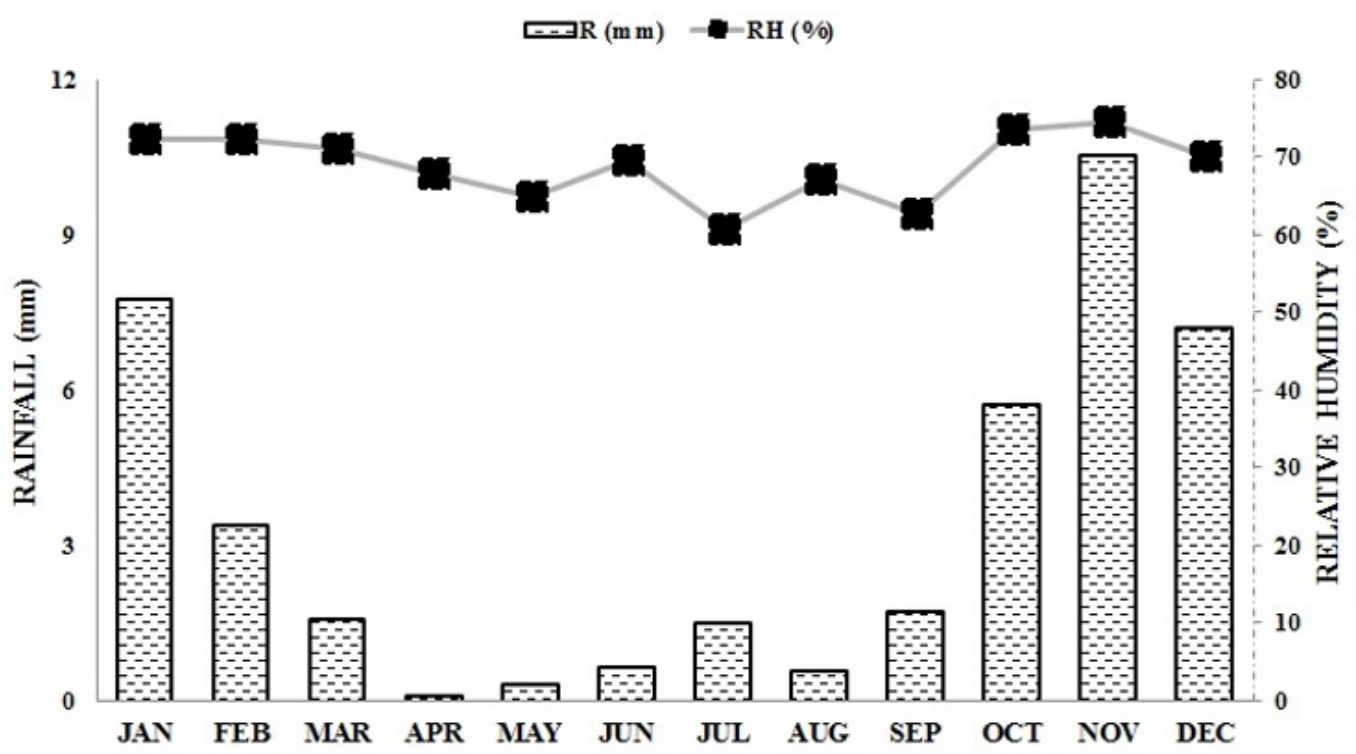

Figure 1: Graphical representation of climatological variables, average relative humidity and rainfall, recorded during 2018 in Lavras-MG (INMET, 2021). 


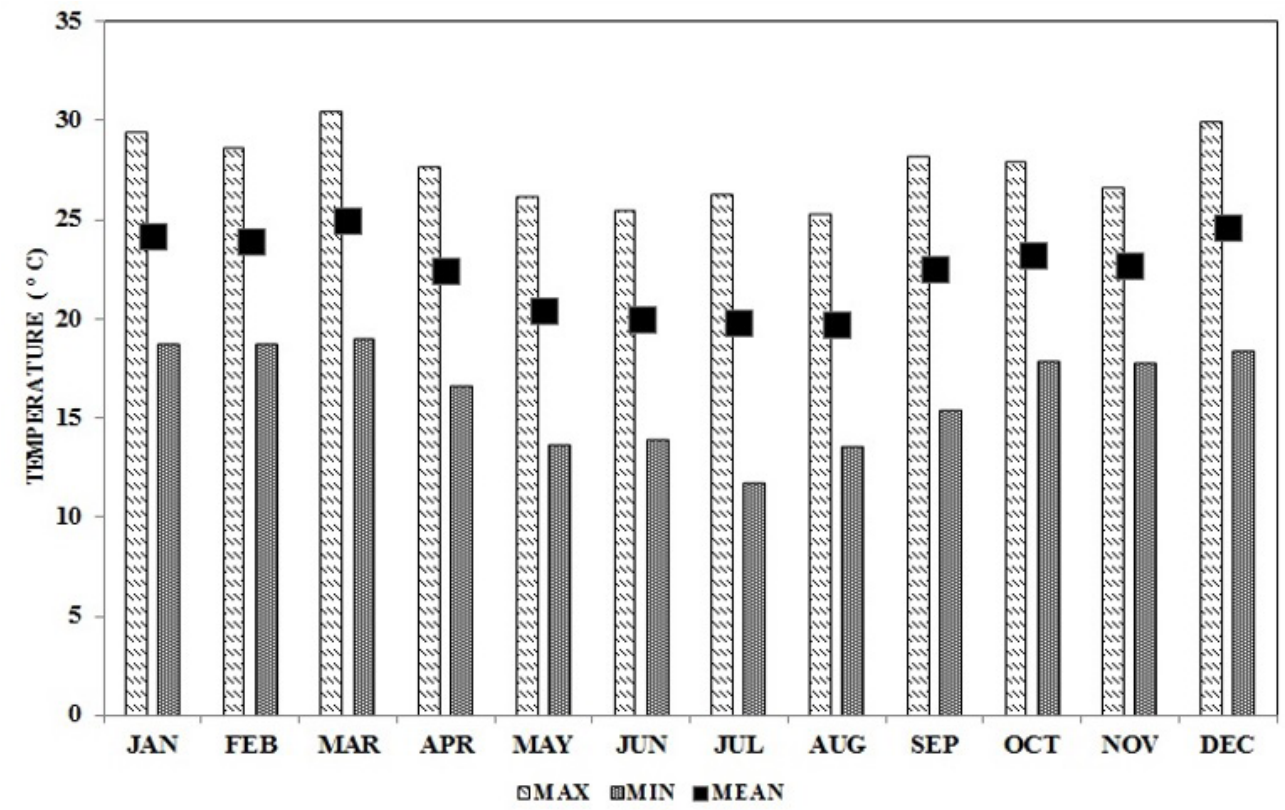

Figure 2: Graphical representation of temperature recorded during 2018 in Lavras-MG (INMET, 2021).

\subsubsection{Yield}

The obtainment of yield was based on two harvests carried out by fruit shedding, in mid-June, 2017 and 2018. Subsequently, the harvested fruits were taken to dry with constant turning, until reaching a water content of $11 \%$ moisture. After coffee processing, the sample was pondered, and then, the conversion calculations for yield (bags ha-1) were determined.

\subsubsection{Statistical analysis}

The data were submitted to variance analysis and the means were grouped according to the Scott-Knott test at $5 \%$ significance. Data analysis was performed by the Genes software (Cruz, 2013).

For the identification of the relevant characteristics in the data variability and the divergence study between progenies, Canonical Variables Analysis was used by the software (R Development Core Team, 2020) through the Candisc package (Friendly; Fox, 2017). To cluster the progenies, the Tocher (Rao, 1952) optimization method was set, which is based on the Mahalanobis Generalized Distance.

\section{RESULTS}

The results obtained in June 2018 in this study were assessed in the dry period, with natural water stress, and values were below the annual average relative humidity between April and May (Figure 1 and 2).

The dissimilarity between "Big Coffee VL" progenies and the importance of each characteristic measured was noticed in the canonical variables analysis. Table 1 shows the correlation amid the characteristics evaluated and the first two canonical variables (Can1 and Can2). Where, the characteristics contribution for progeny differentiation is linked to higher absolute values in canonical variables 1 and 2 .

Table 1: Correlation between characteristics and the first two canonical variables determined in progenies of "Big Coffee VL".

\begin{tabular}{ccc}
\hline Characteristic & Can1 & Can2 \\
\hline $\mathrm{A}$ & -0.7281 & -0.409 \\
$\mathrm{gs}$ & -0.8384 & -0.4369 \\
$\mathrm{Ci}$ & -0.5965 & -0.1451 \\
$\mathrm{E}$ & -0.7193 & 0.53353 \\
$\mathrm{WUE}$ & 0.29109 & -0.6609 \\
$\mathrm{VPD}$ & 0.00479 & 0.41651 \\
$\mathrm{Tleaf}$ & 0.14775 & 0.41106 \\
$\mathrm{Ci} / \mathrm{Ca}$ & 0.03966 & -0.4077 \\
$\mathrm{Cla}$ & 0.06902 & -0.1926 \\
$\mathrm{Clb}$ & 0.1682 & -0.0231 \\
$\mathrm{ClT}$ & 0.15026 & -0.0688 \\
Yield & 0.00378 & -0.8083 \\
\hline
\end{tabular}

The most representative characteristics for the first canonical variable were: stomatal conductance (gs), net photosynthetic rate (A) and transpiration rate (E) (Table 1). On the other hand, for the second canonical variable, the most important characteristics were yield, water use efficiency (WUE) and transpiration rate (E) (Table 1).

For the characteristics evaluated, the first two canonical variables accounted for $79.32 \%$ of the total data variation 
(Figure 3). The first canonical variable accounted for $53.76 \%$ of data variation, and the second, $25.56 \%$.

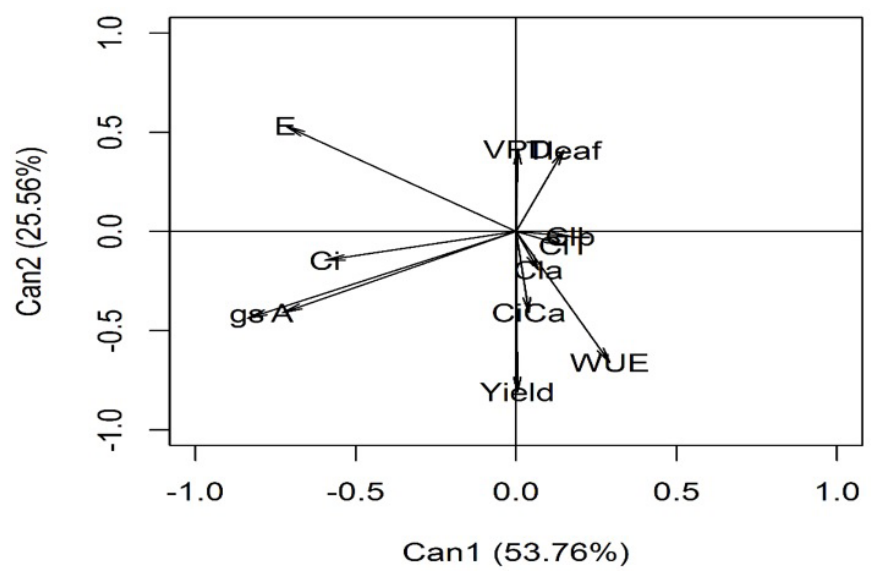

Figure 3: Graphic dispersion of 12 "Big Coffee VL" progenies in relation to the first (Can1) and second (Can2) canonical variables, based on 12 characteristics analyzed: Net photosynthetic rate (A), stomatal conductance (gs), transpiration rate $(E)$, water use efficiency (WUE), internal carbon $(\mathrm{Ci})$, intercellular $\mathrm{CO}_{2}$ concentration in the mesophyll over current external $\mathrm{CO}_{2}$ concentration (Ci/Ca), vapor pressure deficit (VPD), and leaf temperature (Tleaf), relative levels of chlorophylls a (Cla), b (Clb), total (CIT) and yield.

The dissimilarity between progenies was noticed through the graphic dispersion in the first two canonical variables, moreover for the Tocher grouping, which made four distinct groups emphasized in Figure 3. Most progenies assessed were placed in the first group. Progenies S34, M4 and L10 were the most divergent, as they stayed in isolated groups (Figure 4).

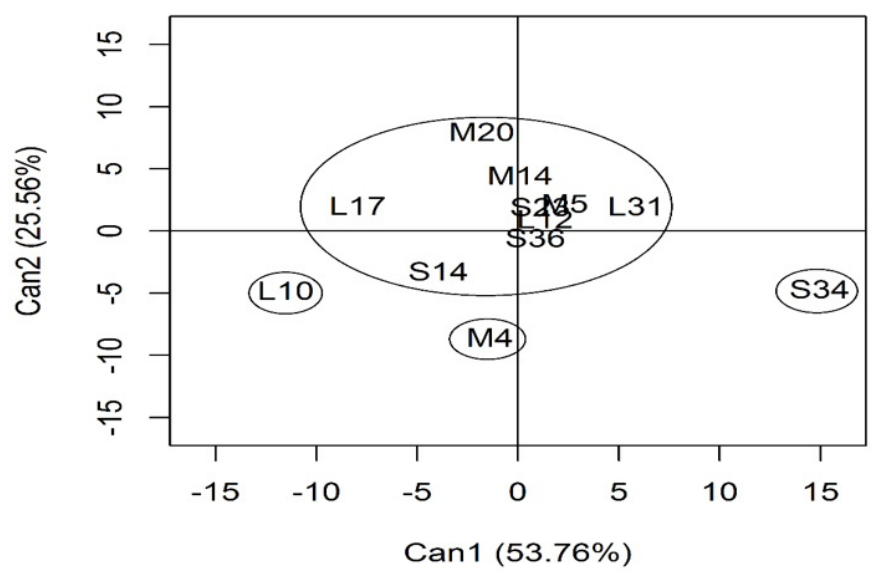

Figure 4: Spatial vector projection of the characteristics evaluated in progenies of "Big Coffee VL" in relation to the first two canonical variables.
From Can1, it can be observed that progeny L10 differed from the others by presenting greater stomatal conductance, net photosynthetic rate (A) and internal carbon concentration (Ci) (Figure 3 and 4).

In progeny $\mathrm{M} 4$, an analogous behavior in relation to L10 was detected, with regard to gas exchange; it is worth mentioning that, in addition to remaining in groups with higher mean values for these characteristics, this progeny lingered with intermediate transpiration, proving to be efficient in water use (Table 2). In progeny S34, there are also greater scores for WUE, in contrast, lesser for A, gs, E and Ci (Figures 3 and 4, Table 2).

In relation to Can2, it was observed that the yield of progeny M4 stands out from the others, while progenies M20 and M14 are highlighted as a function of their higher VPD scores. It is interesting to mention the negative correlation among yield and VPD: higher yields are observed when VPD values are lower (Figures 3 and 4).

Table 2 shows the average values of physiological characteristics and, in Table 3 , the indirect determination of chlorophyll values for the genotypes.

Progenies S36, M4 and L17 showed higher levels of chlorophylls a, b and total (Table 3 ).

The other progenies showed an intermediate behavior in relation to the characteristics above, not having a single characteristic that contributed to a grouping (Figures 3;4, Table 2 and 3).

Yield is an aspect that is always desired in coffee breeding programs. Table 4 and Figure 4 present data from two yield years of the "Big Coffee VL" progenies and their respective biennium averages.

In 2017, progenies S14, S34 and M4 were grouped among the most yielding, followed by progenies S23 and S36, which remained in the second group with the highest yield; progeny L17 revealed low yield (Table 4). In 2018, L17 exhibited the opposite behavior which, together with progeny M4, keep on in the group with the highest yield. The second highest yield group, on the other hand, consisted of progenies L10 and L12, and low yield was observed for the others (Table 4).

Analyzing the biennium, the yield of M4 stood out in relation to the others, followed by the other group, with progenies S14 and S34 (Table 4). Still, when examining the yield of the progeny groups in 2017, groups S and M had greater yield than group L (Figure 5).

In 2018, on the other hand, there was not a significant difference between groups (Figure 5), although group L produced $59 \%$ more in relation to group $\mathrm{S}$ and $34 \%$ in relation to group M. Overall, when considering the biennium yield, there was not a significant difference between the groups (Figure 5). 
Table 2: Mean values of assessed physiological characteristics $A\left(\mu \mathrm{mol} \mathrm{CO} \mathrm{m}^{-2} \mathrm{~s}^{-1}\right), \mathrm{gs}\left(\mathrm{mmol} \mathrm{H}_{2} \mathrm{O} \mathrm{m} \mathrm{m}^{-2} \mathrm{~s}^{-1}\right), \mathrm{Ci}\left(\mu \mathrm{mol} \mathrm{CO} \mathrm{Col}^{-1}\right), \mathrm{E}$ $\left(\mathrm{mmol} \mathrm{m} \mathrm{m}^{-2} \mathrm{~s}^{-1}\right)$, WUE $\left(\mathrm{A} / \mathrm{E}-\mu \mathrm{mol} \mathrm{CO}_{2} / \mathrm{mol} \mathrm{H}_{2} \mathrm{O}\right)$, VPD $(\mathrm{hPa})$, Tleaf $\left({ }^{\circ} \mathrm{C}\right), \mathrm{Ci} / \mathrm{Ca}\left(\mu \mathrm{mol} \mathrm{CO}_{2}\right)$, in progenies of "Big Coffee VL".

\begin{tabular}{|c|c|c|c|c|c|c|c|c|}
\hline PROGENIES & A & gs & $\mathrm{Ci}$ & $\mathrm{E}$ & WUE & VPD & Tleaf & $\mathrm{Ci} / \mathrm{Ca}$ \\
\hline S14 & $8.04 \mathrm{a}$ & $0.11 \mathrm{~b}$ & $282.52 \mathrm{a}$ & $1.46 \mathrm{~b}$ & $5.49 \mathrm{a}$ & $1.19 \mathrm{~b}$ & $23.17 \mathrm{a}$ & $0.72 \mathrm{a}$ \\
\hline $\mathrm{S} 23$ & $6.37 \mathrm{~b}$ & $0.07 \mathrm{c}$ & $273.38 \mathrm{a}$ & $1.30 \mathrm{~b}$ & $4.62 \mathrm{~b}$ & $1.32 \mathrm{~b}$ & $24.15 \mathrm{a}$ & $0.66 \mathrm{~b}$ \\
\hline S34 & $4.55 \mathrm{c}$ & $0.05 \mathrm{~d}$ & $247.95 \mathrm{~b}$ & $0.62 \mathrm{c}$ & $6.11 \mathrm{a}$ & $1.20 \mathrm{~b}$ & $24.53 \mathrm{a}$ & $0.75 \mathrm{a}$ \\
\hline S36 & $6.19 \mathrm{~b}$ & $0.08 \mathrm{c}$ & $281.24 \mathrm{a}$ & $1.27 \mathrm{~b}$ & $4.49 \mathrm{~b}$ & $1.46 \mathrm{a}$ & $24.70 \mathrm{a}$ & $0.65 \mathrm{~b}$ \\
\hline M4 & $8.00 \mathrm{a}$ & $0.11 \mathrm{~b}$ & $257.71 \mathrm{~b}$ & $1.14 \mathrm{~b}$ & $5.62 \mathrm{a}$ & $1.36 \mathrm{~b}$ & $24.41 \mathrm{a}$ & $0.66 \mathrm{~b}$ \\
\hline M5 & $6.58 \mathrm{~b}$ & $0.06 \mathrm{~d}$ & $232.90 \mathrm{c}$ & $1.20 \mathrm{~b}$ & $5.59 \mathrm{a}$ & $1.39 \mathrm{~b}$ & $24.96 \mathrm{a}$ & $0.63 \mathrm{~b}$ \\
\hline M14 & $5.33 \mathrm{c}$ & $0.06 \mathrm{~d}$ & $255.90 \mathrm{~b}$ & $1.48 \mathrm{~b}$ & $3.90 \mathrm{c}$ & $1.80 \mathrm{a}$ & $26.15 \mathrm{a}$ & $0.57 \mathrm{~b}$ \\
\hline M20 & $6.17 \mathrm{~b}$ & $0.08 \mathrm{c}$ & $256.72 b$ & $1.68 \mathrm{a}$ & $4.14 \mathrm{c}$ & $1.58 \mathrm{a}$ & $25.86 \mathrm{a}$ & $0.67 \mathrm{~b}$ \\
\hline L10 & $8.30 \mathrm{a}$ & $0.18 \mathrm{a}$ & $282.16 \mathrm{a}$ & $1.35 \mathrm{~b}$ & $5.79 \mathrm{a}$ & $1.20 \mathrm{~b}$ & $23.32 \mathrm{a}$ & $0.78 \mathrm{a}$ \\
\hline L12 & $6.15 \mathrm{~b}$ & $0.08 \mathrm{c}$ & $256.03 \mathrm{~b}$ & $1.27 \mathrm{~b}$ & $4.88 \mathrm{~b}$ & $1.12 \mathrm{~b}$ & $22.70 \mathrm{a}$ & $0.72 \mathrm{a}$ \\
\hline L31 & $6.18 \mathrm{~b}$ & $0.06 \mathrm{~d}$ & $228.64 \mathrm{c}$ & $1.21 \mathrm{~b}$ & $5.35 \mathrm{a}$ & $1.26 \mathrm{~b}$ & $24.90 \mathrm{a}$ & $0.73 \mathrm{a}$ \\
\hline $\mathrm{CV}(\%)$ & 9.12 & 11.06 & 5.25 & 9.40 & 9.13 & 13.11 & 4.69 & 6.62 \\
\hline
\end{tabular}

Means followed by the same letter in the column belong to the same cluster at $5 \%$ significance by the Scott-Knott test.

Table 3: Indirect determination of the relative levels of chlorophylls a (Cla), b (Clb) and total (CIT) in the progenies of "Big Coffee VL".

\begin{tabular}{cccc}
\hline PROGENIES & Cla & Clb & ClT \\
\hline S14 & $465.33 \mathrm{a}$ & $247 \mathrm{~b}$ & $712.33 \mathrm{a}$ \\
S23 & $445.67 \mathrm{~b}$ & $261.67 \mathrm{~b}$ & $717.00 \mathrm{a}$ \\
S34 & $444.33 \mathrm{~b}$ & $269 \mathrm{~b}$ & $713.33 \mathrm{a}$ \\
S36 & $462.33 \mathrm{a}$ & $293 \mathrm{a}$ & $731.33 \mathrm{a}$ \\
M4 & $459 \mathrm{a}$ & $301 \mathrm{a}$ & $760.00 \mathrm{a}$ \\
M5 & $462.67 \mathrm{a}$ & $261.67 \mathrm{~b}$ & $724.33 \mathrm{a}$ \\
M14 & $448 \mathrm{~b}$ & $266.67 \mathrm{~b}$ & $726.67 \mathrm{a}$ \\
M20 & $421.25 \mathrm{c}$ & $260 \mathrm{~b}$ & $681.25 \mathrm{~b}$ \\
L10 & $426.67 \mathrm{c}$ & $223.33 \mathrm{~b}$ & $650,00 \mathrm{~b}$ \\
L12 & $468.33 \mathrm{a}$ & $273.33 \mathrm{~b}$ & $741.67 \mathrm{a}$ \\
L17 & $462.67 \mathrm{a}$ & $303 \mathrm{a}$ & $765.67 \mathrm{a}$ \\
L31 & $445.33 \mathrm{~b}$ & $271.67 \mathrm{~b}$ & $715.67 \mathrm{a}$ \\
CV(\%) & 9.12 & 11.06 & 5.25
\end{tabular}

Means followed by the same letter in the column belong to the same cluster at $5 \%$ significance by the Scott-Knott test.

\section{DISCUSSION}

Recent studies have shown genetic variability between "Big Coffee VL" progenies, regarding disease resistance, bean size, yield, besides physiological and anatomical characteristics (Castanheira et al., 2016; Pereira et al., 2019; Silva, 2016). In this study, it is possible to observe this variability among the progenies through graphic dispersion, shown in Figures 3 and 4, which was similar to the grouping by Tocher's optimization method. It indicates the effectiveness of the methods used for their differentiation (Pedrosa et al., 2013). Some variables contributed more to progeny dissimilarity, such as A, E and gs (Table 1); the latter molded four distinct groups (Table 2). According to Souza et al. (2016), an important technology to determine plant adaptation in different environments is the gas exchange analysis, which can vary both due to phenological phases and intrinsic and extrinsic factors to the genotype.

Table 4: Average bean yield values (bags ha ${ }^{-1}$ ) in 2017, 2018 and mean values of the progenies of "Big Coffee VL".

\begin{tabular}{cccc}
\hline PROGENIES & 2017 & 2018 & MEAN \\
\hline S14 & $109.46 \mathrm{a}$ & $31.49 \mathrm{c}$ & $70.48 \mathrm{~b}$ \\
S23 & $82.06 \mathrm{~b}$ & $6.48 \mathrm{~d}$ & $44.27 \mathrm{c}$ \\
S34 & $105.86 \mathrm{a}$ & $19.05 \mathrm{~d}$ & $62.46 \mathrm{~b}$ \\
S36 & $81.06 \mathrm{~b}$ & $32.80 \mathrm{c}$ & $55.96 \mathrm{c}$ \\
M4 & $102.39 \mathrm{a}$ & $78.98 \mathrm{a}$ & $90.69 \mathrm{a}$ \\
M5 & $54.95 \mathrm{c}$ & $12.57 \mathrm{~d}$ & $33.76 \mathrm{~d}$ \\
M14 & $53.09 \mathrm{c}$ & $42.06 \mathrm{c}$ & $47.57 \mathrm{c}$ \\
M20 & $54.23 \mathrm{c}$ & $7.67 \mathrm{~d}$ & $30.95 \mathrm{~d}$ \\
L10 & $55.00 \mathrm{c}$ & $52.20 \mathrm{~b}$ & $53.60 \mathrm{c}$ \\
L12 & $26.4 \mathrm{~d}$ & $29.91 \mathrm{c}$ & $28.19 \mathrm{~d}$ \\
L17 & $10.19 \mathrm{e}$ & $74.88 \mathrm{a}$ & $42.53 \mathrm{c}$ \\
L31 & $35.65 \mathrm{~d}$ & $54.50 \mathrm{~b}$ & $45.08 \mathrm{c}$ \\
CV(\%) & 17.83 & 16.54 & 11.06 \\
\hline
\end{tabular}

Means followed by the same letter in the column belong to the same cluster at $5 \%$ significance by the Scott-Knott test. 


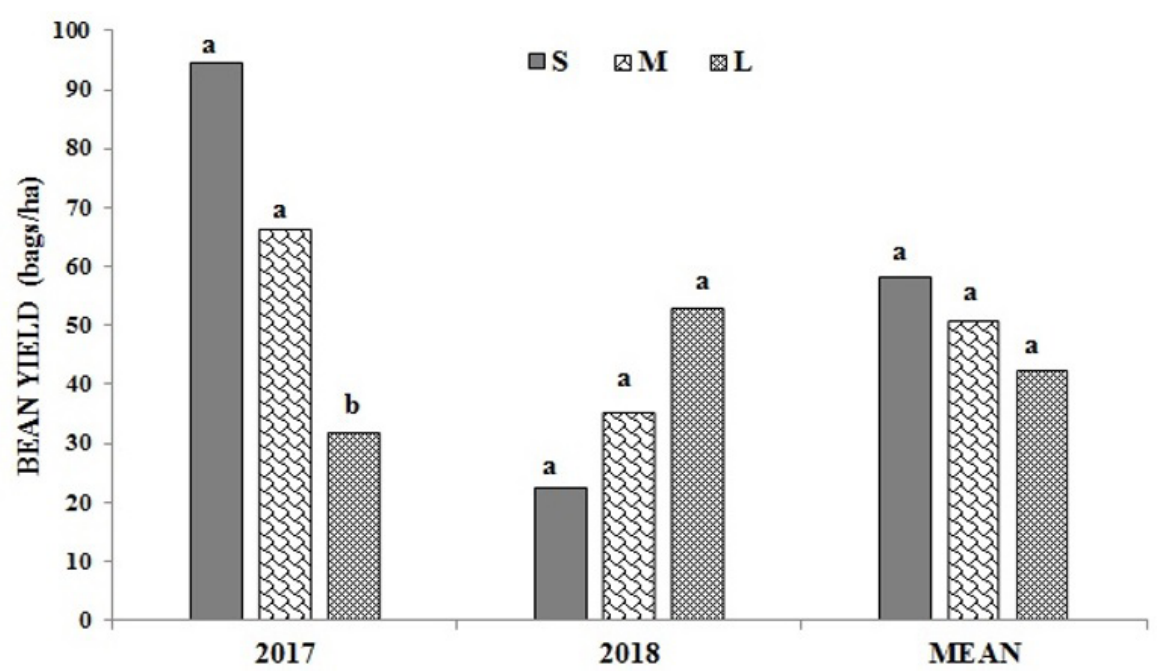

Figure 5: Average yield (bags ha-1) of groups S, M and L of the progenies of "Big Coffee VL" in the years 2017 and 2018.

Temperature and relative humidity are the most important environmental factors involved in coffee stomatal regulation (Ricci; Junior; Almeira, 2013).The results found in June 2018 in this study were evaluated in the dry period, with natural water stress, and values below the annual average relative humidity were recorded between April and May (Figure 1;2).

The ideal temperature and relative humidity $(\mathrm{RH})$ for the development of Coffea arabica $\mathrm{L}$. is 20 to $23{ }^{\circ} \mathrm{C}$ and 70 to $80 \%$, respectively. However, the species manages to be profitable in its production with thermal amplitudes of $17^{\circ} \mathrm{C}$ (minimum), $31.5{ }^{\circ} \mathrm{C}$ (maximum) and between 50 and $80 \%$ of RH, indicating species adaptableness (Fernandes et al., 2012).

At the time of the assessment of this study, there was a fall in relative humidity and low water availability (Figure 1). And even though the progenies were in the same growing environment, there was dissimilarity among them in reply to abiotic conditions. Water use efficiency by the coffee tree can be an adaptation mechanism in the face of this natural stress period (Durand et al., 2019), which generally causes a decline in stomatal conductance and transpiration rate, triggering a decrease in the photosynthetic rate (Dalastra et al., 2014); this behavior is proven by progeny S34 (Table 2).

Although this progeny remained in the group with the highest water use efficiency (Table 2), the reduction in transpiration rate limited the influx of $\mathrm{CO}_{2}$ and there was a reduction in the photosynthetic rate, in this progeny. In contrast, the progenies S14, M4 and L10, maintained carbon assimilation, reduced transpiration, controlling stomatal opening and closing, without affecting the photosynthesis process (Table 2). In addition, these progenies stood out in relation to yield (Table 4).

In this context, beneficial correlations were found in Coffea arabica $\mathrm{L}$. between water use efficiency and relative productivity, proposing that the selection for high water use efficiency scores can favor these characteristics (DaMatta et al., 2016).

To carry out photosynthesis, several factors are necessary, among them, $\mathrm{CO}_{2}$ availability. Thus, for this gas influx, the plant requires a longer period of stomatal opening, resulting in higher internal carbon concentrations (Tatagiba; Pezzopane; Reis, 2015; Shimazaki et al., 2007). Consequently, there is a rise in $\mathrm{CO}_{2}$ intercellular concentration in the mesophyll over the current external $\mathrm{CO}_{2}$ concentration $(\mathrm{Ci} / \mathrm{Ca})$; such an event is elucidated by progeny L10 (Table 2). Souza et al. (2020) also observed a similar behavior for Arabica coffee 'Mundo Novo' and 'Acauã', which stood out with high values for A, compared to other cultivars studied, owing to its higher values for gs and $\mathrm{Ci} / \mathrm{Ca}$.

When the plant goes through a climatic condition in which there is low relative humidity, there is an increase in the atmosphere evaporative demand (greater vapor pressure deficit - VPD) (Lemos et al., 2012). This characteristic has a direct relationship with stomatal condutance, the increase in VPD leads to stomatal closure, in order to prevent excessive transpiration and photosynthetic rate decreases. Stomatal limitations in growth and fruit filling are responsible for the range in the carbon assimilation among the phenological phases (Silva et al., 2020), affecting plant growth and development and, consequently, yield (Durand et al., 2019; $\mathrm{Li}$ et al., 2019). Such circumstance was observed in progeny M14, which recorded a high vapor pressure deficit, declining the net photosynthetic rate and stomatal conductance (Table 2), consequently, the yield falls (Table 4).

Progenies S36, M4 and L17 stood out in the chlorophyll contents (Table 3), pigments that, with the aid of NADPH and ATP, convert light radiation into chemical energy (Taiz; Zeiger, 2013). The concentration of these chlorophylls is positively linked with the leaf nitrogen content, due to the fact that nearly $70 \%$ of this element is present in chloroplasts, 
participating in the synthesis and structure of the respective pigments (Gil et al., 2002). Therefore, this set of factors can favor high yield observed in progeny L17, in 2018, and M4 in the two years measured, indicating a good adaptability of the latter in relation to the growing conditions (Table 3; Table 4).

Plants with low yield can invest in vegetative growth, according to Reis et al. (2018), which probably happened to progeny S34, wherein its photoassimilates may have been translocated to developing regions for the high load of fruit yielded in 2017 (Table 4). This fact is due to the fruits acting as priority drains, so that the dry matter allocation to them tends to be greater than that assigned to the growth of the vegetative branches throughout the annual yield cycle, according to the estimate of Vaast et al. (2005).

It is known that in years of high fruit load, the plant has difficulty in keeping the growth demand for fruits and vegetative organs in a balanced way (Rena; Maestri, 1985). The coffee tree is characterized by the well-defined phenological cycle of vegetative and reproductive period, where the plant in its reproduction already structures the growth of the new branches and flower buds responsible for the next harvest; subsequently, a high photoassimilate synthesis is necessary to meet the demand of the two phases (Camargo; Camargo, 2001).

\section{CONCLUSION}

The progenies of "Big Coffee VL" show variability for physiological parameters and productivity. Progenies S14, M4 and L10 stood out, and S14 was more efficient in the use of water, M4 was the most productive and L10 stood out in terms of gas exchange.

\section{ACKNOWLEDGEMENTS.}

The authors thank for INCT Café, Fapemig and Consórcio Pesquisa Café, for the financial support for the project; and $\mathrm{CNPq}$, for the productivity (GRC).

\section{REFERENCES}

BARBIERI JÚNIOR, E. et al. Um novo clorofilômetro para estimar os teores de clorofila em folhas do capim Tifton 85. Ciência Rural, 42(12):2242-2245, 2012.

CAMARGO, A. P. de; CAMARGO, M. B. P. de. Definição e esquematização das fases fenológicas do cafeeiro arábica nas condições tropicais do Brasil. Bragantia, 60(1):6568, 2001.

CARVALHO, C. H. S. de. et al. Cultivares de café arábica de porte baixo. In: CARVALHO, C. H. S. de. (Ed.). Cultivares de café: Origem, características e recomendações. Brasília, DF: EMBRAPA Café, 2008. 334p.
CASTANHEIRA, D. T. et al. Potencial de utilização de características anatômicas e fisiológicas na seleção de progênies de cafeeiro. Coffee Science, 11(3):375-386, 2016.

CILAS, C.; MONTAGNON, C.; BAR-HEN, A. Yield stability in clones of Coffea canephora in the short and medium term: Longitudinal data analyses and measures of stability over time. Tree Genetics \& Genomes, 7(2):421-429, 2011.

\section{COMPANHIA NACIONAL DE ABASTECIMENTO -} CONAB. Acompanhamento da safra brasileira de café de 2020. Brasília, 2020. Available in: <www.conab.gov. br>. Access in: March, 23, 2021.

\section{CONSELHO DOS EXPORTADORES DE CAFÉ DO} BRASIL - CECAFE. Relatório mensal outubro 2018. Available in: $<$ http://www.cecafe.com.br $>$. Access in: November, 28, 2018.

CRUZ, C. D. GENES - A software package for analysis in experimental statistics and quantitative genetics. Acta Scientiarum. Agronomy, 35(3):271-276, 2013.

DALASTRA, G. M. et al. Trocas gasosas e produtividade de três cultivares de meloeiro conduzidas com um e dois frutos por planta. Bragantia, 73(4):365-371, 2014.

DAMATTA, F. M. et al. Sustained enhancement of photosynthesis in coffee trees grown under free-air $\mathrm{CO}_{2}$ enrichment conditions: Disentangling the contributions of stomatal, mesophyll, and biochemical limitations. Journal of Experimental Botany, 67(1):341-352, 2016.

DAMATTA, F. M. et al. Why could the coffee crop endure climate change and global warming to a greater extent than previously estimated? Climate Change, 152(1):167-178, 2019.

DURAND, M. et al. Altered stomatal dynamics induced by changes in irradiance and vapor-pressure deficit under drought: impacts on the whole-plant transpiration efficiency of poplar genotypes. New Phytologist, 222(4):1798-1802, 2019.

FERNANDES, A. L. T. et al. A moderna cafeicultura dos cerrados brasileiros. Pesquisa Agropecuária Tropical, 42(2):232-240, 2012.

FERREIRA, A. D. et al. Desempenho agronômico de seleções de café Bourbon Vermelho e Bourbon Amarelo de diferentes origens. Pesquisa Agropecuária Brasileira, 48(4):388-394, 2013.

FRIENDLY, M.; FOX, J. Candisc: Visualizing generalized canonical discriminant and canonical correlation analysis. R package version 0.8-0. 2017. Available in: $<$ https:// cran.r-project.org/web/packages/candisc $>$. 2017. Access in: July, 08, 2020. 
GARCIA, N. et al. Waterlogging tolerance of five soybean genotypes through different physiological and biochemical mechanisms. Environmental and Experimental Botany, 172:e103975, 2020.

GIL, P. T. et al. Índice SPAD para o diagnóstico do estado de nitrogênio e para o prognóstico da produtividade da batata. Horticultura Brasileira, 20(4):611-615, 2002.

INSTITUTO NACIONAL DE METEOROLOGIA INMET. BDMEP dados históricos. 2021. Available in: $<$ http://www.inmet.gov.br/portal/>. Access in: March, 25,2021

LEMOS, J. P. et al. Morfologia de plantas de milho em competição com picão-preto e trapoeraba submetidas a roçada. Planta Daninha, 30(3):487-496, 2012.

LI, J. et al. Seasonal change in response of stomatal conductance to vapor pressure deficit and three phytohormones in three tree species. Plant Signaling \& Behavior, 14(12):e1682341, 2019.

PEDROSA, A. W. et al. Crescimento de cultivares de café em resposta a doses contrastantes de zinco. Coffee Science, 8(3):295-305, 2013.

PEREIRA, F. A. C. et al. Selection of coffee progenies with large beans resistant to rust and cercospora leaf spot. Coffee Science, 14(1):67-75, 2019.

R DEVELOPMENT CORE TEAM. R: A language and environment for statistical computing. R Foundation for Statistical Computing. Version 4.0.3 2020. Vienna, Austria. Available in: <http://www.R-project.org/>. Access in: July, 08, 2020.

RAO, C. R. Advanced statistical methods in biometric research. New York: Willey, 1952. 390p.

REIS, E. A. C. et al. Characterization of coffee cultivars leaf rust-resistant subjected to framework pruning. Coffee Science, 13(1):63-70, 2018.

RENA, A. B.; MAESTRI, M. Fisiologia do cafeeiro. Informe Agropecuário, 11(126):26-40, 1985.

RICCI M. S. F.; JUNIOR C. D. G.; ALMEIRA F. F. D. Condições microclimáticas, fenologia e morfologia externa de cafeeiros em sistemas arborizados e a pleno sol. Coffee Science, 8(3):379-388, 2013.

RODRIGUES, W. P. et al. Whole-canopy gas exchanges in Coffea sp. is affected by supra-optimal temperature and light distribution within the canopy: The insights from an improved multi-chamber system. Scientia Horticulturae, 211:194-202, 2016.

SAKIYAMA, N. et al. Café arábica do plantio a colheita. Viçosa, Editora UFV, 2015. 316p.

SHIMAZAKI, K. I. et al. Light regulation of stomatal movement. Annual Review of Plant Biology, 58(1):219247, 2007.

SILVA, J. et al. Genetic diversity among coffee tree progenies big coffee VL based on growth traits and production. Genetics and Molecular Research, 15(4):1-8, 2016.

SILVA ÁVILA, E. A. da et al. Relationship of gas exchanges in different phenological phases with coffee productivity in the Cerrado. Research, Society and Development, 9(7):e293974123, 2020.

SOUZA, B. P. de et al. Gas exchanges and chlorophyll fluorescence of young coffee plants submitted to water and nitrogen stresses. Journal of Plant Nutrition, 43(16):2455-2465, 2020.

SOUZA, T. M. A. et al. Crescimento e trocas gasosas do feijão caupi cv. BRS pujante sob níveis de água disponível no solo e cobertura morta. Irriga, 21(4):796$805,2016$.

TAIZ, L.; ZEIGER, E. Fisiologia vegetal. 5a edição. Porto Alegre: Artmed, 2013. 918p.

TATAGIBA, S. D.; PEZZOPANE, J. E. M.; REIS, E. F. Fotossíntese em Eucalyptus sob diferentes condições edafoclimáticas. Engenhariana Agricultura, 23(4):336$345,2015$.

VAAST, P. et al. Fruit load and branch ring-barking affect carbon allocation and photosynthesis of leaf and fruit of Coffea arabica in the field. Treephysiology, 25(6):753-760, 2005.

VENTURIN, R. P. et al. A pesquisa e as mudanças climáticas na cafeicultura. Informe Agropecuário, 34:34-43, 2013. 